\title{
MONITORING TRAINING LOAD AND RECOVERY IN VOLLEYBALL PLAYERS DURING A SEASON
}

\author{
MONITORAMENTO DA CARGA DE TREINAMENTO ERECUPERAÇÃO EM JOGADORES DE VOLEIBOL \\ DURANTE UMA TEMPORADA
}

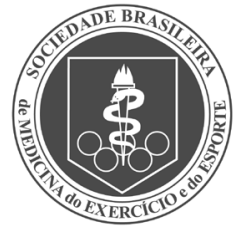

Original Article ARTIGO ORIGINAL Artículo Original

\author{
MONITOREO DE LA CARGA DE ENTRENAMIENTO Y RECUPERACIÓN EN JUGADORES DE VOLEIBOL \\ DURANTE UNA TEMPORADA
}

\begin{abstract}
Thiago Seixas Duarte ${ }^{1}$
(Physical Education Professional)

Danilo Reis Coimbra²

(Physical Education Professional)

Renato Miranda'

(Physical Education Professional)

Heglison Custódio Toledo3

(Physical Education Professional)

Francisco Zacaron Werneck ${ }^{4}$

(Physical Education Professional)

Daniel Gustavo Schimitz de Freitas 5

(Physical Education Professional)

Mauricio Gáttas Bara Filho'

(Physical Education Professional)
\end{abstract}

1. Universidade Federal de Juiz de Fora. Faculty of Physical Education and Sport, Center for Research on Training Load Control, Juiz de Fora, MG, Brazil.

2. Universidade do Estado de Santa Catarina. Department of Health Sciences, Center for Health and Sport Sciences, Joinville, SC, Brazil. 3. Universidade Federal de Juiz de Fora, Campus Avançado de Governador Valadares, Faculty of Physical Education and Sport. Governador Valadares, MG, Brazil. 4. Universidade Federal de Ouro Preto, Center for Sport, Laboratory for Studies and Research on Exercise and Sport, Ouro Preto, MG, Brazil.

5. Universidade Salgado de Oliveira, Physical Education Department, Juiz de Fora, MG, Brazil.

\section{Correspondence:}

Thiago Seixas Duarte

Rua Dom Viçoso 290/202, Alto dos Passos, Juiz de Fora, MG, Brazil. 36026-390. tseixas.ef@gmail.com

\begin{abstract}
Introduction: Monitoring training loads, along with the recovery status, is important for preventing unwanted adaptations. Knowledge of these variables over volleyball seasons is still scarce. Objective: To monitor and describe the training load and recovery status of volleyball players over a competitive season. Methods: The sample consisted of 14 professional volleyball players. For the entire season, the training load was monitored daily by the SPE method during the session, and the recovery status was monitored by TQR and QBE on the first and last days of training for the week. Results: There was a decrease in training load between Preparatory Period I and Competitive Period I $(p=0.03)$, followed by an increase in Preparatory Period II $(p<0.001)$ and a new decrease in Competitive Periods II ( $p=0.01)$ and III $(p=0.003)$. There was a significant reduction between Pre-TQR and QBE and Post-TQR and QBE in all mesocycles. In the Pre-TQR, there was a reduction between Preparatory Period II and Competitive Period II $(p=0.006)$, in the Pre-QBE, there was a reduction between Preparatory Period II and Competitive Period III ( $p=0.002)$, and in the Post-TQR, this reduction was observed between Competitive Period I and Preparatory Period II ( $p=0.03)$. In the Post-QBE, there was an increase between Preparatory Period I and Competitive Period I $(p=0.002)$, followed by a decrease in Preparatory Period II $(p=0.01)$. Conclusion: Loads varied throughout the season, along with recovery, which varied according to the loads and characteristics of each period. Level of evidence I, Therapeutic Studies - Investigating the Results of Treatment.
\end{abstract}

Keywords: Volleyball; Monitoring; Recovery.

\section{RESUMO}

Introdução: O monitoramento das cargas de treinamento junto com o estado de recuperação é importante na prevenção de adaptações indesejadas. Ainda é escasso o conhecimento dessas variáveis ao longo das temporadas de voleibol. Objetivo: Monitorar e descrever a carga de treinamento e o estado de recuperação de atletas de voleibol ao longo de uma temporada competitiva. Métodos: A amostra foi composta de 14 atletas profissionais de voleibol. Ao Iongo de toda a temporada, a carga de treinamento foi monitorada diariamente pelo método da PSE da sessão eo estado de recuperação foi monitorado pela TQR Q QBE, no primeiro eúltimo dia de treinamento da semana. Resultados: Houve queda na carga de treino do Período Preparatório I para o Período Competitivo I $(p=0,03)$, seguida de aumento no Período Preparatório II $(p<0,001)$ e nova queda no Período Competitivo II $(p=0,01)$ e III $(p=0,003)$. Ocorreu redução significativa da TQR e QBE Pré para a TQR e QBE Pós em todos os mesociclos. Na TQR Pré houve queda do Período Preparatório Il para o Período Competitivo II ( $p=0,006)$, já na QBE Pré houve redução do Período Competitivo Il para o Período Competitivo III $(p=0,002)$ e na TQR Pós essa diminuição foi observada do Período Competitivo I para o Período Preparatório II $(p=0,03)$. Na QBE Pós observou-se aumento do Período Preparatório I para o Período Competitivo I $(p=0,002)$, seguido de queda no Período Preparatório II $(p=0,01)$. Conclusão: As cargas apresentaram variação ao longo da temporada, juntamente com a recuperação, que variou em função das cargas e das características de cada período. Nível de evidência l; Estudos terapêuticos - Investigação dos resultados do tratamento.

Descritores: Voleibol; Monitoramento; Recuperação.

\section{RESUMEN}

Introducción: El monitoreo de las cargas de entrenamiento junto con el estado de recuperación es importante en la prevención de adaptaciones no deseadas. Todavía es escaso el conocimiento de esas variables a lo largo de las temporadas de voleibol. Objetivo: Monitorear y describir la carga de entrenamiento y el estado de recuperación de atletas de voleibol a lo largo de una temporada competitiva. Métodos: La muestra fue compuesta de 14 atletas profesionales de voleibol. A lo largo de toda la temporada, la carga de entrenamiento fue monitoreada diariamente por el método de la PSE de la sesión y el estado de recuperación fue monitoreado por TQR y QBE, en el primery último día de entrenamiento de la semana. Resultados: Hubo una caída en la carga de entrenamiento del Período Preparatorio I para el Período Competitivo I ( $p=0,03)$, seguida de un aumento en el Período Preparatorio II $(p<0,001)$ y una nueva caída en el Período Competitivo II $(p=0,01)$ y III $(p=0,003)$. Se produjo una reducción significativa de la TQRy QBE Pre para la TQR y QBE Post en todos los mesociclos. En la TQR Pre hubo caída del Período Preparatorio Il para el Período 
Competitivo II $(p=0,006)$, ya en la QBE Pre hubo reducción del Período Competitivo II para el Período Competitivo III $(p=0,002)$ y en la TQR Post esta disminución fue observada del Período Competitivo I para el Período Preparatorio II ( $p=0,03)$. En la QBE Post se observó aumento del Período Preparatorio I para el Período Competitivo I $(p=0,002)$, seguido de caída en el Período Preparatorio II $(p=0,01)$. Conclusión: Las cargas presentaron variación a lo largo de la temporada, junto con la recuperación, que varía en función de las cargas y de las características de cada período.

\section{Nivel de evidencia l, Estudios terapéuticos - Investigación de los resultados del tratamiento.}

\section{Descriptores: Voleibol; Monitoreo; Recuperación.}

\section{INTRODUCTION}

Sports training aims to improve athlete performance. To achieve this, the training load must be appropriately applied in terms of intensity and volume, followed by a recovery period to prepare the athlete's body for new loads. During this period, the the athlete's physical, psychological and sports capabilities are restored. ${ }^{1-4}$

In collective sports, the annual calendar usually consists of a preparatory period ${ }^{5,6}$ followed by the competitive period. The main competitive season (Superliga) of Brazilian volleyball lasts for five to six months and usually consists of games held once or twice a week. ${ }^{7}$ It is thus important to monitor the athletes during this period, allowing them to execute the planned training load and achieve the expected performance. ${ }^{8}$

It is important to monitor the training load along with the recovery state, making sure that the recovery periods are consistent with the training loads, minimizing any negative training adaptations. ${ }^{1,2,9}$

Different tools can be used to monitor the athlete's load and recovery. Of these tools, the psychometric ones have been effective and are simple, easily applied and inexpensive..$^{10-13}$ The tools used to assess recovery include the Total Quality Recovery (TQR) scale and the Well-Being Questionnaire (WB). 2,11

Although some studies monitor training loads in volleyball at some points during the season, ${ }^{14-16}$ there is still a lack of studies on the recovery state behavior along the season, of how the characteristics of some periods will influence it to help understand the recovery and its variables in volleyball.

The objective of this study was to monitor and describe the training load and recovery state of volleyball athletes during a competitive season, and to compare the behavior of these variables at different times of the season.

\section{METHODS}

\section{Sample}

The study included 14 male athletes from an adult volleyball team competing in the National Superliga championship, with mean age of $24.0 \pm 3.59$ years, body mass of $96.87 \pm 9.85 \mathrm{~kg}$, height of $194.36 \pm 6.9 \mathrm{~cm}$, fat percentage of $7.58 \pm 1.91 \%$.

The athletes were informed of the potential risks involved in the process and attested to voluntary participation. They allowed the use and dissemination of information. This study has been approved by the Research Ethics Committee under no. 964.012.

This study was carried out during a competitive season lasting 35 weeks, divided into five mesocycles named as follows:

- Seven weeks of preparatory period I,

- Five weeks of competitive period I,

- Eight weeks of preparatory period II,

- Eight weeks of competitive period II,

- Seven weeks of competitive period III.

During the competitive period I, the athletes participated in a state competition; competitive period II corresponds to the first round of the national competition and competitive period III corresponds to the second round of the same competition. During preparatory periods I and II, friendlies and regional championships were performed.

Internal load monitoring was performed using the subjective perceived exertion method. ${ }^{17}$ Thirty minutes after the end of each training session, the athletes answered the following question: "How was your training?", based on Borg CR10 adapted scale. To calculate the training load $(\mathrm{TL})$, the marker recommended by the athlete multiplied by the training time was used. On days with two training shifts, the TL of the sessions was added up. The total weekly training load (TWTL) was calculated by adding up the daily TLs of the week. As the periods presented different durations, the mean TWTL of each period was determined.

To monitor the recovery state, the Total Recovery Quality Scale (TQR) was used.

This scale was proposed in order to evaluate general recovery. Athletes answered the question "How do you feel about your recovery?", based on the scale proposed by Kentta and Hassmen, ${ }^{2}$ in which 6 corresponds to "Not recovered" and 20, "Completely recovered."The athletes responded to the scale on the first and last day of training or game in the week.

To evaluate subjective perception of fatigue, sleep quality, general muscular pain, stress level and mood, the Well-Being Questionnaire (WB) proposed by McLean, Coutts ${ }^{11}$ was applied based on the recommendations of Hooper and Mackinnon. ${ }^{18}$

This is a psychometric questionnaire in which the five previously mentioned items are evaluated in scales ranging from one (worst values) to five (best values) points, and each one of these values is accompanied by a specific descriptor of the item evaluated. The total Sum of all scales generates a value that is considered Total Well-Being. The athletes answered the scale on the first and last day of training or game of the week.

\section{Statistical analysis}

Descriptive statistics is presented as mean \pm standard deviation. Data normality was confirmed using the Shapiro-Wilk test. In order to test differences in TWTL, WB and TQR among the mesocycles, repeated measures ANOVA was used, followed by multiple comparison of means with Bonferroni correction. When the sphericity assumption was not met, the degrees of freedom were corrected by Huynh-Feldt's epsilon. For this analysis, the mean of the variables in the respective weeks of each mesocycle was considered. To test correlations between the variables WB, TQR and TWTL, Pearson's correlation coefficient was used. To test correlations between WB and TWTL, Spearman's correlation test was used. All analyses were conducted in the statistics software SPSS version 20.0 (IBM Corp., Armonk, NY), adopting a significance level of 5\%.

\section{RESULTS}

Table 1 shows the descriptive values of TWTL, WB and TQR in the different mesocycles of the season. A significant difference was observed in $T L\left(F_{(4,52)}=12.147 ; p<0.001\right.$; eta $\left.^{2}=0,48\right)$, in the Pre WB $\left(F_{(4,52)}=6.532\right.$; $\mathrm{p}<0.001$; eta $\left.{ }^{2}=0.33\right)$, Post $W B\left(F_{(4,52)}=2.942 ; p=0.03 ;\right.$ eta $\left.^{2}=0.18\right)$, Pre $T Q R$ $\left(F_{(4,52)}=5.262 ; p=0.001 ;\right.$ eta $\left.^{2}=0.29\right)$ between the mesocycles. On the other 
hand, no significant difference was observed in the Post TQR $\left(F_{(4.52)}=1.032\right.$; $\mathrm{p}=0.40$, eta ${ }^{2}=0.07$ ) among the mesocycles.

There was a decrease in the TWTL of Preparatory Period I for Competitive Period I ( $p=0.03)$, followed by an increase in the TL of Preparatory Period II $(p<0.001)$ and a new decrease in Competitive Period II $(p=0.01)$ and III ( $p=0.003$ ). The statistical differences found were between successive periods. (Figure 1)

There was a significant reduction from Pre TQR to Post TQR in all mesocycles. (Figure 2)

In all mesocycles, there was a significant difference in Pre WB vs. Post WB, with a decrease in General Well-Being at the end of the week compared to the beginning of the week. (Figure 3)

Considering the whole season, a positive and statistically significant correlation was observed between PreWB and PreTQR, $(r=0.63 ; p<0.001$; $n=392)$. There was also a positive and statistically significant correlation between Post WB and Post TQR ( $r=0.45 ; \mathrm{p}<0.001 ; n=392)$. Besides, TL

Table 1. Mean \pm standard deviation of training load $(T L)$, perceived well-being (WB) and recovery (TQR) at the beginning of the week (Pre) and at the end of the week (Post) of a volleyball team ( $n=14)$ over 5 mesocycles of the season.

\begin{tabular}{c|c|c|c|c|c}
\hline & TWTL & Pre WB & Post WB & Pre TQR & Post TQR \\
\hline Preparatory period I & $3664.4 \pm 508.6$ & $19.9 \pm 1.4$ & $17.4 \pm 1.8$ & $16.4 \pm 1.3$ & $14.5 \pm 1.1$ \\
\hline Competitive period I & $3384.6 \pm 570^{*}$ & $19.8 \pm 1.2$ & $18.7 \pm 1.5^{*}$ & $16.4 \pm 0.9$ & $14.7 \pm 1.1$ \\
\hline Preparatory period I & $4546, \pm 620.9^{*}$ & $20.2 \pm 1.8$ & $17.7 \pm 1.3 *$ & $16.7 \pm 1.1$ & $14.1 \pm 0.8 *$ \\
\hline Competitive period II & $4006.6 \pm 687.6^{*}$ & $20.4 \pm 1.7$ & $18.1 \pm 1.5$ & $15.9 \pm 1.1 *$ & $14.3 \pm 1.3$ \\
\hline Competitive period II & $3599.8 \pm 853.7 *$ & $18.5 \pm 2.1^{*}$ & $17.8 \pm 1.1$ & $15.7 \pm 1.1$ & $14.2 \pm 1.1$ \\
\hline (*Significant differences between the mesocycles; p $<0.05$ ).
\end{tabular}

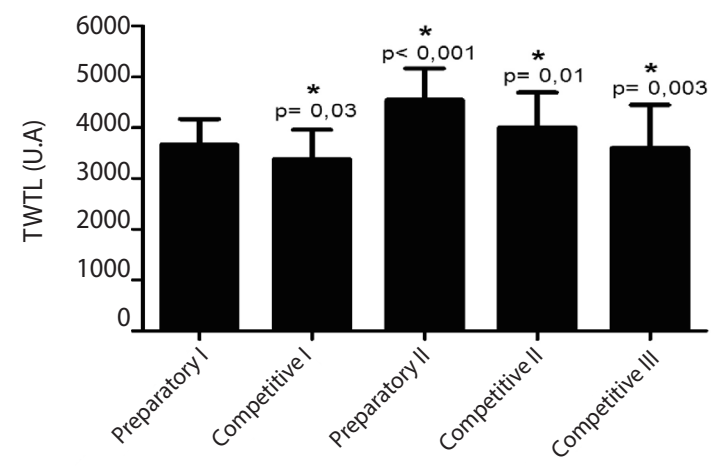

Figure 1. Mean \pm standard deviation of the training load (TL) of a volleyball team $(n=14)$ measured over five mesocycles of the season (*Significant differences found compared to the previous mesocycle, $p<0.05$ ).

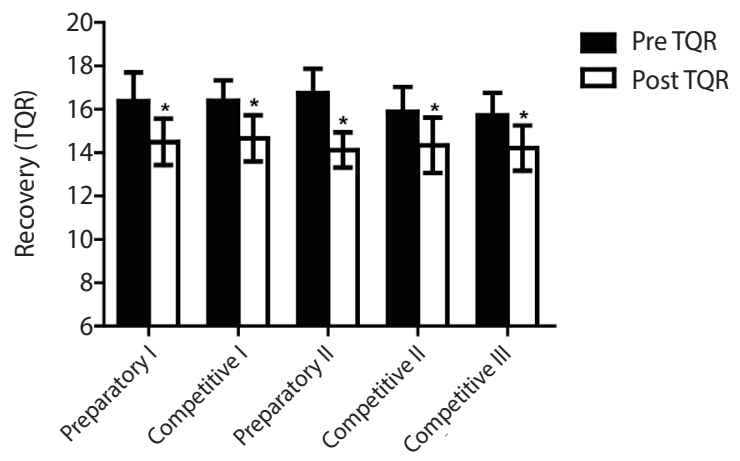

Figure 2. Mean \pm standard deviation of the total quality recovery (TQR) at the beginning and at the end end of the week for a volleyball team $(n=14)$ measured over five mesocycles of the 2012/2013 season. ( ${ }^{*}$ Significant differences between Pre TQR and Post TQR; $p<0.05)$

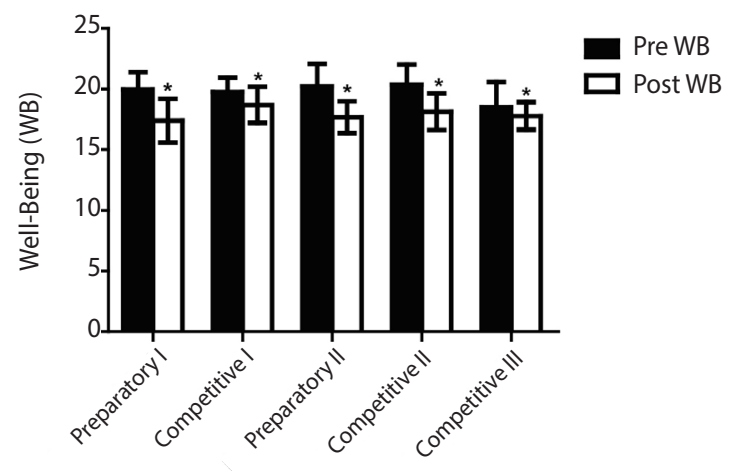

Figure 3. Mean \pm standard deviation of Well-Being Questionnaire (WB) at the beginning and at the end of the week of a volleyball team $(n=14)$ measured over five mesocycles of the 2012/2013 season. (*Significant differences between Pre WB and Post WB; $p<0.05)$.

showed a negative and statistically significant correlation with Post WB $(r=-0.23 ; p<0.001 ; n=392)$ and with Post TQR $(r=-0.36 ; p<0.001 ; n=392)$.

Considering the periods of the season, a negative and statistically significant correlation was found between post-training fatigue $(r=-0.3 ; p<0.003 ; n=98)$, post-training sleep quality ( $r=-0.35 ; p<0.001$; $n=98)$, post-training humor ( $r=-0.423 ; p<0.001 ; n=98)$ and post-training stress level $(r=-0.3 ; p<0.003 ; n=98)$ and the TWTL of preparatory period I. In competitive period I, there was a negative and statistically significant correlation between post fatigue $(r=-0,25 ; p<0.04 ; n=70)$ e post general muscular pain ( $r=0.35 ; \mathrm{p}<0.003 ; \mathrm{n}=70)$ and TWTL. In preparatory period $I I$, there was a negative and statistically significant correlation between post fatigue ( $r=-0.29 ; \mathrm{p}<0.004 ; \mathrm{n}=98)$ and TWTL. This correlation also occurred in competitive period II, but with other values ( $r=-0.31 ; p<0.019 ; n=55)$. In competitive period III, no significant correlations were found.

\section{DISCUSSION}

This study aimed to monitor training loads and recovery state during different periods of the season.

The results showed that the training load fluctuated according to the characteristics of each mesocycle. Manzi and D'Ottavio ${ }^{19}$ found a significant difference in TWTL in weeks with and without matches; the training loads for weeks without games were higher than those in weeks with one or two games, corroborating our findings for the decreased TWTL in competitive periods.

Regarding the load values found in other studies with volleyball athletes, only one was similar to the values found in this study, with values ranging from $4138 \pm 664$ to $4427 \pm 409$ U.A during two weeks of intensification of training loads. ${ }^{15}$ In the study by Horta et al. ${ }^{16}$, the load

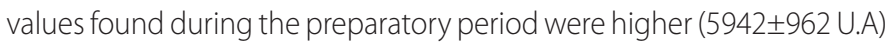
compared to our study.

According to our results, the TQR and WB methods for the quantification of recovery state were sensitive to the load variation during the season. The behavior of these variables at the beginning and at the end of each period was possibly related to the load applied during the period, proving to be useful tools to monitor the responses of applied loads.

The differences found in post-TQR between competitive periods I and preparatory period || can be explained by the magnitude of the loads applied in both periods. A similar result was reported by Freitas and Nakamura ${ }^{15}$ in volleyball athletes. Suzuki and Sato ${ }^{13}$ also demonstrated this characteristic in a case study with race athletes: during the season where the TL was higher, the TQR was lower. This demonstrates that TQR can also be a TL control tool. 
The difference found in pre TQR between preparatory period II and competitive period II is possibly due to the characteristics of the competitive period in question, with games played twice a week with intervals shorter than or equal to 48 hours between them, trips and limited number of days off. During this period, strategies should be adopted to make sure the athletes' recovery state is not further impaired during the week, such as training in a period of the day, seeking an alternative to increase the athletes' free time during the competitive period and using methods that accelerate the recovery process between the matches. ${ }^{9,20}$

This is the first study, to our knowledge, that used the Well-Being Questionnaire (WB) in volleyball athletes during a full season. The results indicated that in preparatory periods I and II, post WB was statistically lower in both periods compared to competitive period I. This can be explained by the training loads applied in each period analyzed. Buchheit and Racinais ${ }^{21}$ demonstrated that WB was sensitive to training load variations during the preparatory period in soccer players.

The correlation values found between TQR and WB, both in pre collection ( $r=0.63$ ) and in post collection ( $r=0.45$ ), show that these have consistent measures and that one adds information to the other. TQR is a simpler tool, while WB provides more detail about recovery factors.

In preparatory period I, of the five items assessed by WB at the end of the week, four presented a significant correlation with TWTL.
It is believed that with the resumed training routine, this period with high loads may have generated such responses. ${ }^{6,22}$ In preparatory period II, fatigue was the only item that showed a significant correlation with TWTL, indicating a better adaptation of the athletes.

\section{CONCLUSION AND PRACTICAL APPLICATIONS}

The results of this study allow us to conclude that the internal training loads varied throughout the season, indicating higher loads in the preparatory periods compared to the competitive periods in volleyball. It is considered that the recovery of athletes varied according to the loads and characteristics of the period in which the team was in the season. Besides, these results confirm the effectiveness of the subjective perceived exertion method for monitoring training load in volleyball. The Total Quality Recovery Scale (TQR) and Well-Being Questionnaire (WB) were effective in monitoring recovery, which was shown to be sensitive to the training loads applied during the season.

\section{ACKNOWLEDGEMENTS}

The authors acknowledge Coordenação de Aperfeiçoamento de Pessoal de Nível Superior (CAPES) for their financial support.

All authors declare no potential conflict of interest related to this article

AUTHORS' CONTRIBUTIONS: Each author made significant individual contributions to this manuscript. TSD (0000-0002-7394-8519)*: contributed substantially to writing the manuscript and the conception of the work; DRC (0000-0002-6055-0667)*: contributed substantially to the conception of the work and critical review of the intellectual content; RM (0000-0002-1127-8513)*: took part in the final approval of the version and critical review of the intellectual content of the manuscript; HCT (0000-0001-6066-9011)*: took part in the final review of the version and critical review of the intellectual content of the manuscript; FZW (0000-0003-1966-8820)*: performed the statistical analysis of the data and interpretation of the results; DGSF (0000-0002-2494-3287)*: contributed substantially to the conception of the work and critical review of the intellectual content; MGBF (0000-0003-1219-8379)*: took part in the final approval of the version and contributed substantially to the conception of the work and critical review of the intellectual content. All authors approved the final version of the manuscript. *ORCID (Open Researcher and Contributor ID).

\section{REFERENCES}

1. Kellmann M. Preventing overtraining in athletes in high-intensity sports and stress/recovery monitoring. Scand J Med Sci Sports. 2010;(Suppl 2):95-102..

2. Kentta G, Hassmen P. Overtraining and recovery. A conceptual model. Sports Med. 1998;26(1):1-16.

3. Halson $S L$, Jeukendrup AE. Does overtraining exist? An analysis of overreaching and overtraining research. Sports Med. 2004;34(14):967-81.

4. Issurin VB. New horizons for the methodology and physiology of training periodization. Sports Med. 2010;40(3):189-206.

5. Miloski B, Freitas VHd, Bara Filho MG. Monitoramento da carga interna de treinamento em jogadores de futsal ao longo de uma temporada. Rev Bras Cineant Desemp Hum. 2012;14:671-9.

6. Moreira A, Bilsborough JC, Sullivan CJ, Ciancosi M, Aoki MS, Coutts AJ. Training periodization of professional Australian football players during an entire Australian Football League season. Int J Sports Physiol Perform. 2015;10(5):566-71.

7. Sheppard JM, Gabbett TJ, Stanganelli LC. An analysis of playing positions in elite men's volleyball: considerations for competition demands and physiologic characteristics. J Strength Cond Res. 2009;23(6):1858-66.

8. Venter RE. Perceptions of team athletes on the importance of recovery modalities. Eur J Sport Sci. 2014;14(Suppl 1):S69-76.

9. Bishop PA, Jones E, Woods AK. Recovery from training: a brief review. J Strength Cond Res. 2008;22(3):1015-24.

10. Brink MS, Nederhof E, Visscher C, Schmikli SL, Lemmink KA. Monitoring load, recovery, and performance in young elite soccer players. J Strength Cond Res. 2010;24(3):597-603.

11. McLean BD, Coutts AJ, Kelly V, McGuigan MR, Cormack SJ. Neuromuscular, endocrine, and perceptual fatigue responses during different length between-match microcycles in professional rugby league players. Int J Sports Physiol Perform. 2010;5(3):367-83.

12. Nakamura FY, Moreira A, Aoki MS. Monitoramento da carga de treinamento: a percepção subjetiva do esforço da sessão é um método confiável? Rev Educ Fis. 2010;21(1):1-11
13. Suzuki S, Sato T, Maeda A, Takahashi A. Program design based on a mathematical model using rating of perceived exertion for an elite japanese sprinter: a case study. J Strength Cond Res. 2006;20(1):36-42.

14. Freitas VH, Miloski B, Bara Filho MG. Monitoramento da carga interna de um período de treinamento em jogadores de voleibol. Rev Bras Educ Fis Esporte. 2015;29:5-12.

15. Freitas VH, Nakamura FY, Miloski B, Samulski D, Bara-Filho MG. Sensitivity of physiological and psychological markers to training load intensification in volleyball players. J Sports Sci Med. 2014;13(3):571-9.

16. Horta TAG, Bara Filho MG, Coimbra DR, Miranda R, Werneck FZ. Training load, physical performance, biochemical markers, and psychological stress During a short preparatory period in Brazilian elite male volleyball players. J Strength Cond Res. 2017 [acesso em 2018 abr 19]: Disponível em: https:// www.ncbi.nlm.nih.gov/pubmed/29239985.

17. Foster C, Florhaug JA, Franklin J, Gottschall L, Hrovatin LA, Parker S, et al. A new approach to monitoring exercise training. J Strength Cond Res. 2001;15(1):109-15.

18. Hooper SL, Mackinnon LT. Monitoring overtraining in athletes. Recommendations. Sports Med. 1995;20(5):321-7.

19. Manzi V, D'Ottavio S, Impellizzeri FM, Chaouachi A, Chamari K, Castagna C. Profile of weekly training load in elite male professional basketball players. J Strength Cond Res. 2010;24(5):1399-406.

20. Barnett A. Using recovery modalities between training sessions in elite athletes: does it help? Sports Med. 2006:36(9):781-96.

21. Buchheit M, Racinais S, Bilsborough JC, Bourdon PC, Voss SC, Hocking J, et al. Monitoring fitness, fatigue and running performance during a pre-season training camp in elite football players. J Sci Med Sport. 2013;16(6):550-5

22. Jeong T-S, Reilly T, Morton J, Bae S-W, Drust B. Quantification of the physiological loading of one week of "pre-season" and one week of "in-season" training in professional soccer players. J Sports Sci. 2011;29(11):1161-6. 